\title{
Climate change in the North - past, present and future
}

1 Alfred-Wegner-Institute for Polar and Marine Research in the Helmholtz-Association, Am Handelshafen 12, D-27570 Bremerhaven, Germany.E-mail: Joern.Thiede@awi.de

2 Nansen Environmental and Remote Sensing Centre (NERSC), Geophysical Institute, University of Bergen, Thormöhlensgate 47, N-5006 Bergen, Norway. E-mail: Ola.Johannessen@nersc.no

The Nordic countries have produced famous polar explorers and researchers who have generated climate research schools at a variety of locations. The dependence of these countries with respect to the lifelihood of their societies, of their use of lands and seas, the exploitation of marine living and non-living resources have made climate research an eminent topic, and many outstanding discoveries of long-and short-term climate change have been made for the first time in Scandinavia. These include early contributions to our understanding of the geological effects of continent-wide glaciations during the ice ages, the complex postglacial history of the Baltic Sea and the varved sediment sequences preserved from lakes with an extraordinary seasonality in their sediment input, as well as the detailed records of temperature, ice texture and impurities and greenhouse gas variations of the last Glacial and of the Holocene preserved in the ice cores from Greenland. Iceland with its volcanic sequences and intercalated sediment layers not only preserved the history of this subaerial segment of the mid-Atlantic Ridge, but also easily datable paleoclimate records. The fate of the Vikings, who settled during the Medieval climate optimum on Iceland and later on Greenland and who lost their habitat on Greenland at the beginning of the Little Ice Age, illustrates vividly the climate-dependent subsistence of the indigenous and non-indigenous Scandinavian populations. Modern Scandinavian climate research institutions also include sophisticated modelling groups.

\section{Why study the climate and its temporal variability?}

Much of northwestern Europe and what is now Norden was buried under ice at the end of the last Glacial and Man could only migrate northwards after the Fennoscandian ice sheet receded. He did so early and with great success, but understood quickly that his well being depended on the climatic conditions. Medieval written records allow us to trace the build-up of relatively rich agricultural societies, which under the influence of the onset of the Little Ice Age and the Black Death in the 14th century, suffered severe losses. Fisheries
Vid - Selsk. Skr. 1.Math - nab. Kl. 1906, No3. Pl.II
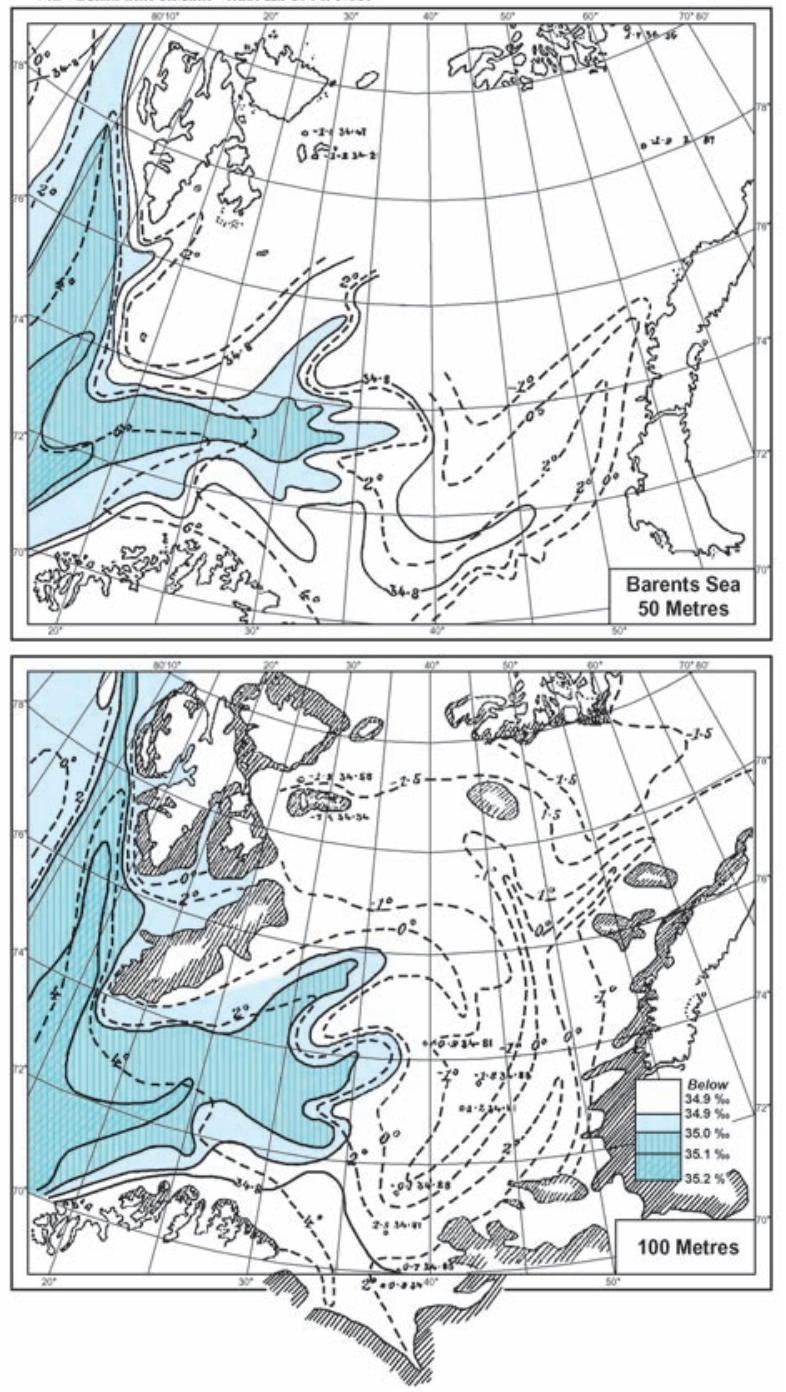

Figure 1 Sea surface temperatures off Northern Norway and distribution of major water masses, published by Nansen (1906), based on the oceanographic observations of Amundsen during 1901.

along the west coast off Norway were dependent upon climatic and oceanographic conditions, and the possibilities to sail across the Norwegian-Greenland Sea were subject to sea-ice distribution.

Nordic countries and academic institutions have therefore been a "Mecca" for climate and paleoclimate research from early on because the people concerned were keenly aware of the exposed geographic location of their countries in high northern latitudes, 
while enjoying relatively benign living conditions, extraordinarily comfortable as compared to other countries/continents like northern Siberia or North America at the same latitudes.

It was century-old knowledge that while the surface waters of the western Norwegian Sea and Greenland Sea off Greenland was cold and partly sea-ice covered, waters immediately off-shore Norway were much warmer and the home to important fisheries. Norwegian oceanographers soon began systematic investigations of the hydrographic properties of the major currents systems off Norway and they detected that an extension of the Gulf Stream System (now called the Norwegian Current) reached the Barents Sea and Svalbard (Nansen, 1906); hence, they understood that the regional extension of the temperate climate zones into high northern latitudes was closely linked to the atmospheric circulation over the northern hemisphere and the hydrography of the surface waters of the ocean basin adjacent to the Scandinavian peninsula (Figure 1). And it was also Nansen (1925) who speculated about the correlation of the impact of climate change on the fate of the Vikings who had settled on Greenland during the Medieval climatic optimum, but who had lost the ability for transoceanic voyages under the severe sea-ice conditions during the onset of the the Little Ice Age.

Meteorology and oceanography therefore developed early at a number of Scandinavian academic institutions because they were driven by the needs of shipping and fisheries. Successful polar expeditions such as those by Nordenskjöld, Nansen and Amundsen gave these disciplines a high public profile. The constructions of the Norwegian ships Fram and Maud, as the first dedicated purpose-built polar research vessels, represented milestones in this development because they provided for the first time state of the art, at that time modern scientific working platforms which at the same time guaranteed safety and healthy living conditions for their crews. It is therefore surprising that terrestrial paleoclimatology, in particular terrestrial Quaternary geology, emerged much earlier than its marine counterparts, namely paleoceanography and marine geology. The needs of weather forecasting and the increasing computing capabilities during the past 50 years created opportunities to model future climate scenarios, which are being continuously refined.

\section{Terrestrial records of climate change}

There is a substantial chapter devoted to the "Quaternary of Norden" by Wohlfahrt and others elsewhere in this volume which covers many aspects of climate change during the latest period of Earth history. But evidence for extreme climates over Scandinavia are not restricted to the Cenozoic, because outstanding discoveries have also been made to our understanding of glaciations older than the Cenozoic. Stratigraphic sequences with world famous outcrops of late pre-Cambrian tillites are known from the Varanger Peninsula in northern Norway and from the Sparagmite Basin near Oslo (Björlykke et al., 1976).

In countries like the Nordic ones, whose morphology was extensively reshaped during the Cenozoic glaciations and interglaciations, it was only natural that geoscientists tried to understand how and when this could have been happened. Studies of Paleogene sequences and their floras on Svalbard suggested long ago (Heer, 1876) that glaciations were relatively young and that widespread glaciations on the northern hemisphere only developed much later.

Esmark competed with his contemporaries on the nature and origin of glacial deposits and a rich culture of Quaternary research groups evolved in all of the Nordic countries (Wolfarth et al., 2008). They made contributions to the extent of the ice sheets, the nature of the interglacials, and the stratigraphy of Pleistocene and Holocene terrestrial and limnic deposits (Mangerud, 1982) based on a wide variety of techniques. Particular important were considerations of the interplay between isostatic and eustatic sea level changes and the extent of ice sheets. A particularly good example is the late Pleistocene and Holocene paleogeographic and paleoenvironmental his- tory of the Baltic Sea basin (cf. Wohlfarth et al., 2008). Lately Scandinavian Quaternary geologists and paleoclimatologists have extended their studies to distant areas, mainly under the framework of international projects like PONAM (Funder et al., 1994) and QUEEN (Thiede et al., 2004; cf. Wohlfarth et al., 2008).

The probably most important contributions to Late Quaternary paleoclimatic studies come from the ice core research on Greenland, which started several decades ago in Copenhagen, under the leadership of Willy Dansgaard. By now, international teams are involved in collecting ice cores from all over world because they seem to provide excellent and, in part, very detailed records of temperature changes, of the historical variations of some of the most important greenhouse gases, as well as of impurities from a wide variety, but climatically often significant sources. In Figure 2, the most important features of the North Greenland Ice Core (North Greenland Ice Core Project Members, 2004) are illustrated; the glacial DansgaardOeschger events display a series of short lived and dramatic climatic warming events interrupting the cold glacial climate over Greenland over very short spans of time, whereas the interglacial climates, in particular in the Holocene, are enigmatically stable. In Figure 2, the ice core record from Greenland is compared to data from the adjacent North Atlantic Ocean (Bauch and Kandiano, 2007) illustrating the intimate response of the paleoceanographic variability of ocean surface and bottom waters to the climatic changes observed over northern Greenland. The upper part of the Greenland ice core also clearly displays the early Holocene climatic optimum tending towards cooler temperatures afterwards. It will be highly exciting to trace the variabilities of tempartures and greenhouse gases in the youngest parts of ice cores, both from Greenland and from Antarctica.
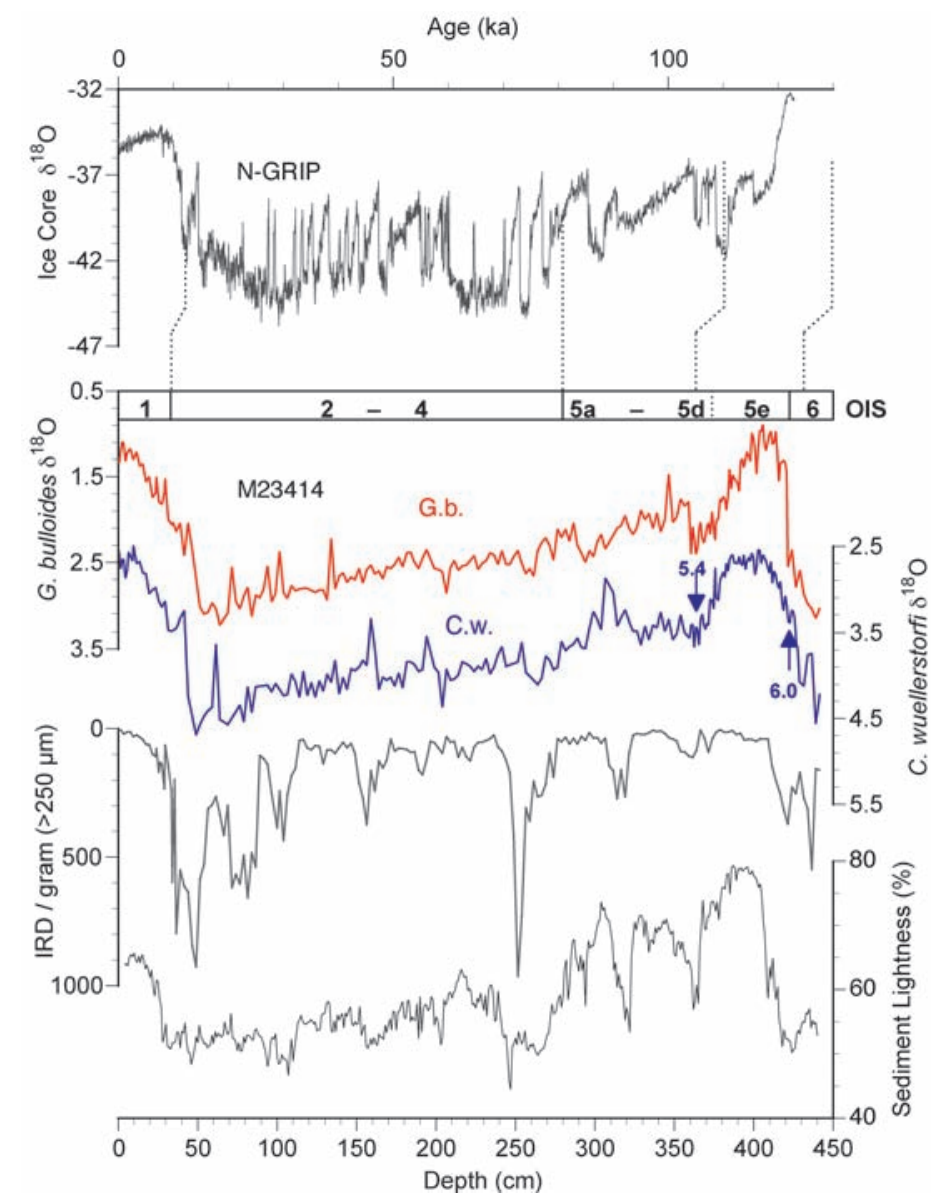

Figure 2 Comparison of Greenland ice core data (North Greenland Ice Core Project Members, 2004), in the upper panel, with proxy records from a North Atlantic sediment core M23414 (after Bauch and Kandiano, 2007, courtesy Dr. Henning Bauch, Kiel). 


\section{Paleoceanography and the history of seas in high northern latitudes}

Despite the tradition in meteorology, oceanography and Quaternary geology, studies of the paleoenvironmental history of the Norwegian-Greenland Sea and of the Arctic Ocean only took off when Hans Holtedal (1955) studied the first sediment cores from the southern Norwegian Sea and detected the important changes in sediment composition at the transition from the last glacial maximum to the Holocene. He was preceded by the Swedish ALBATROSS expedition which circum-navigated the world and collected numerous sediment cores for paleoceanographic studies, mostly from tropical to subtropical seas (Olausson, 1996); these laid a foundation for many of the later stratigraphic studies of pelagic sediments. In the meantime, important research schools in several academic environments in high northern latitutes have risen from these early investigations.

Some 30 years ago, marine geophysicists succeeded to unravel the plate tectonic history of the Norwegian-Greenland Sea and of the eastern Arctic Ocean. The patterns of sea-floor spreading-type magnetic anomalies suggested that these ocean basins had started to open sometime between anomaly 24 and 25 . Soon after these discoveries, the "Glomar Challenger" of the Deep-Sea Drilling Project visited the Norwegian-Greenland Sea during DSDP Leg 38, led by co-chief scientists Manik Talwani and Gleb Udintsev, to address four scientific questions, namely 1) the tectonic framework and evolution of the area, 2) the youngest times of the existence of land bridges between Eurasia and North America, 3) the date of initiation of northern hemisphere glaciations, and 4) to find Tertiary microfaunas and -floras. They succeeded splendidly and laid the groundwork for later legs of the "JOIDES Resolution" (Figure 3) which, under the framework of the International Ocean Drilling Program, visited the Norwegian-Greenland Sea during three expeditions (Leg 104-Dipping reflectors of the Vöring Plateau and history of the Norwegian Current, 151-North Atlantic Arctic Gateways I, 162-North Atlantic Arctic Gateways II). During Leg 151, the "JOIDES Resolution" even succeeded-accompanied by the icebreaker "Fennica" - to enter ice-free waters to the north of Svalbard, thereby bringing a scientific drill-ship for the first time into the Arctic Ocean. Lately, ECORD (the European Consortium of Ocean Research Drilling under the framework of the new Integrated Ocean Drilling Program) has organized a major drilling effort in the permanently sea-ice-covered central Arctic Ocean by sending a flotilla of three ice-breakers (including a drilling vessel) to the Lomonosov Ridge at a position very close to the North Pole (the ACEX expedition led by co-chiefs Jan Backman and Kate Moran). A host of new data addressing the four major themes already defined for DSDP Leg 38 have been collected as the results of these drilling efforts; contrary to common believe the Northern Hemisphere seems to have experienced widespread glaciations since Eocene times (St. John, in press).

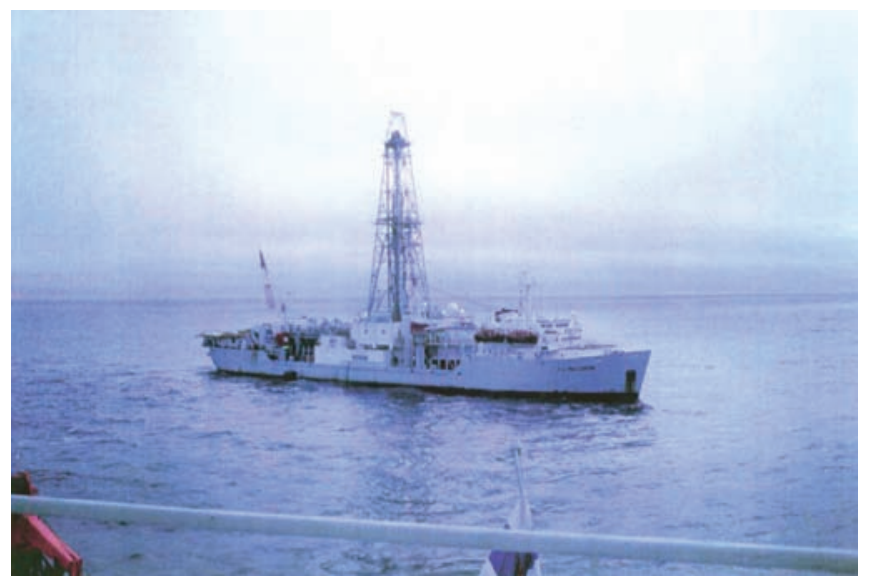

Figure 3 JOIDES Resolution during ODP Leg 151 in the Fram Strait (Myhre, Thiede, Firth et al., 1995).

\section{Modern arctic climates and their variability as expressed in the sea-ice cover and the oceanography of the Nordic Seas}

Climate has a "memory" and modern climate scenarios can therefore only be understood, if we also have some knowledge of its historical variability, at various time scales. It has been clear for quite some time that the distribution of the Arctic sea-ice cover is a highly sensitive climate indicator. During the late 1970s, increased international interest led to new studies in the Marginal Ice Zone (MIZ) of the Nordic Seas. Several large international experiments took place such as the Norwegian Remote Sensing experiment in 1979 (NORSEX 79), the mega-science Marginal Ice Zone Experiment in 1983-1984-1987 (MIZEX 83, MIZEX 84, MIZEX 87), and the Seasonal Ice Zone Experiment in 1989 (SIZEX 1989), see Johannessen et al. (1992). The overall objectives of these experiments were to improve our understanding of the air-ice-ocean processes in the MIZ and to develop and validate remote sensing techniques. The concept and the strategy of all these experiments were to collect data from a three-level observational system-satellites, aircraft, and in-situ observations. Instruments on these varied platforms acquired a diverse suite of ice, ocean, and atmospheric data. From these experiments, we started to understand the mesoscale processes in the Seasonal Ice Zone (Figure 4). For example we learned that mesoscale ice-ocean eddies along the ice edge were very efficient in melting the ice edge. Furthermore that upwelling took place along the ice edge which is important for biological production during summer time.

Reviews of fragmentary observational evidence, taken together, provide a reasonably coherent picture of Arctic and subarctic change, indicating that the last 2-3 decades have experienced unusual warming over northern Eurasia and North America, reduced Arctic sea-ice, marked changes in Arctic Ocean hydrography, reduced glaciers and snow cover, increased runoff into the Arctic, increased tree growth in northern Eurasia, and reduced tundra areas and thawing (Johannessen et al., 2005). There have been fragmen-

Total ice cover $=$ Multi-year ice cover + First-year ice cover
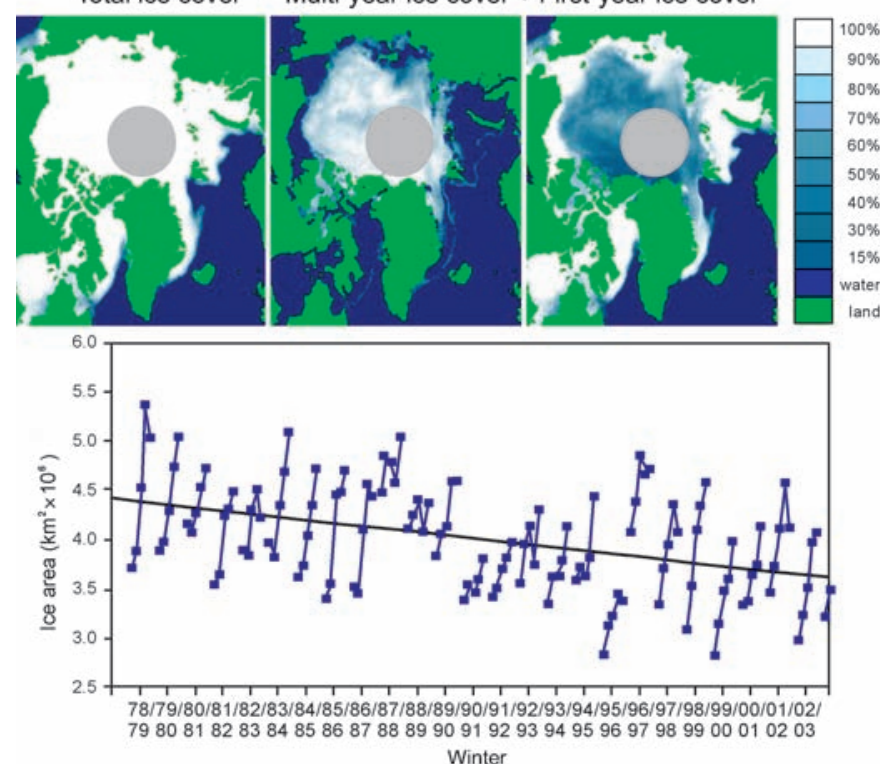

Figure 4 Upper three pictures-Arctic total sea-ice concentration (left) and its two components: multi-year (center) and first-year (right) ice, derived from satellite passive-microwave sensor data. The grey scale indicates the fraction (\%) of each ice type (black $=$ $0 \%$, white $=100 \%)$. The lower diagram shows the variability and trend in multi-year ice area in winter, 1978-98. Source: Johannessen et al. (1999). 
tary indications of unusual conditions in recent years, such as reduced ice concentration in the Siberian sector of the perennial ice pack in the 1990s and reduced ice thickness in parts of the Arctic since the 1970s (Johannessen et al., 1999). For example, Figure 5 infers the temporal evolution of the zonally averaged anomalies of annual mean surface air temperature from 30 to 90 degrees N. Two characteristic warming events stand out; the first from the mid 1920s to 1940 and the second starting about 1980 and still ongoing. Johannessen et al. (2004) inferred that the early warming was caused by natural variability and that the present warming was mainly caused by the increasing greenhouse gases of the atmosphere.

Complementary to the Arctic sea-ice and atmospheric changes, studied in the above-mentioned analyses, are changes in physical oceanography on similar time scales. This was studied through Norwegian-Russian collaboration (Bobylev et al., 2003). A similar early 20th Century warming was seen in the Atlantic Water (AW) temperature in the Arctic Ocean. Furthermore oceanographic data covering the period 1950-98 were compiled and used to determine interannual to decadal variations in the convective intensity and water mass structure in the Greenland Sea and adjacent areas. Extremely cold winters throughout 1965-70 intensified the vertical water exchange in the Norwegian-Greenland Sea. As a result, cold and fresh Greenland Sea Deep Water (GSDW) production was extremely high in the central Greenland Sea, while in the southern Norwegian Sea, warm and saline water spread downward. Long observational series obtained from Ocean Weather Station M confirmed the existence of layers with advection-driven high oxygen concentrations in intermediate and deep layers. A simultaneous rise in the NAO (North Atlantic Oscillation) index and GSDW temperature indicates a link between the atmosphere and the thermohaline circulation (THC).

\section{The 21st century Arctic and European climate}

In the beginning of the 1990s (Figure 5), when global warming started to be a major topic, the interest for studying the arctic climate increased. A consensus from coupled atmosphere-ice-ocean modelling studies of increasing greenhouse-gas (GHGs) scenarios is that anthropogenic global warming will be enhanced in the northern high latitudes, due to complex feedback mechanisms in the atmosphere-ocean-ice system. The predicted warming in the Arctic over the next 50 years is $\sim 3-4^{\circ} \mathrm{C}$ or more than twice the global average. This suggests that the Arctic may be where the most rapid and dramatic changes (e.g., a shrinking sea-ice cover) take place during the 21 st century.

The NAO, the major mode of atmospheric variability in the Northern Hemisphere, particularly in winter, is exerting a strong control on the extra-tropical climate, e.g., modulating the westerly jet stream and temperature from eastern North America into Eurasia.

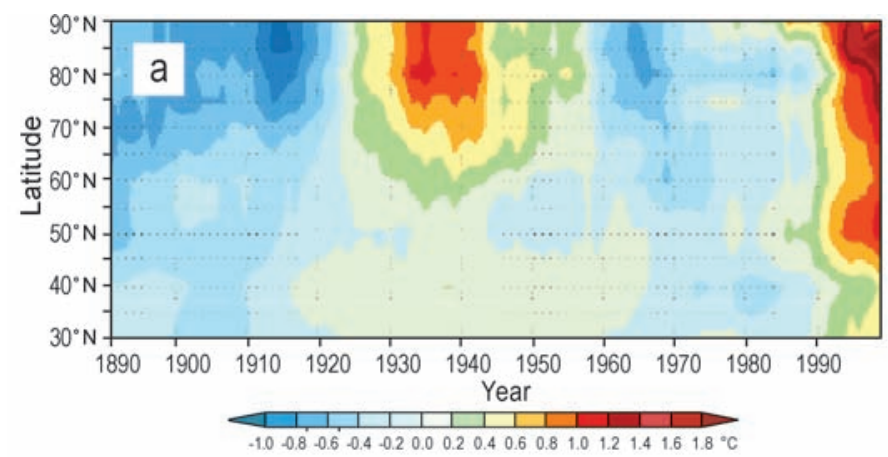

Figure 5 Hovmöller diagram of the time-latitude variability of surface air temperature (SAT) north of $30^{\circ} \mathrm{N}$ from 1891 to 1999 (Johannessen et al., 2004).
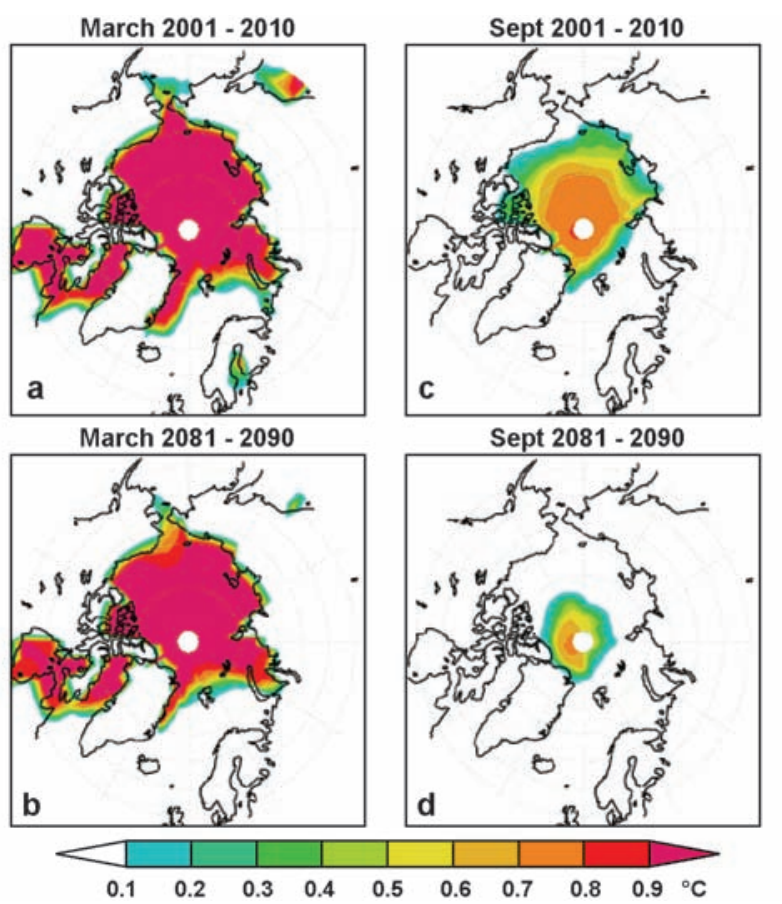

Figure 6 ECHAM4-modelled Northern Hemisphere sea-ice concentration in late winter (March) from (a) 2001-10 and (b) 2081-90, and in late summer (September) from (c) 2001-10 and (d) 2081-90. From Johannessen et al. (2004).

The NAO has exhibited a positive trend since the 1960s and it has been speculated that this may be linked to global warming. However, the observed variations in the NAO could also be caused by natural variations in the climate system. It has been difficult to uniquely state which of the two alternatives are most likely, as distinguishing natural versus anthropogenic variability in the NAO, based on observed surface-level pressure (SLP) alone, is challenging. There are also uncertainties in the theoretical response of NAO/AO (Arctic Oscillation) to enhanced greenhouse warming and our ability to model it realistically using numerical models.

The underlying causes of forced variability in the North Atlantic region are unclear. There are at least two candidate mechanisms to explain the recent trend of the NAO. The one involves an extra-tropical response to changes in tropical sea-surface temperature; the other appeals to stratospheric changes. The spatial distributions of the modelled sea-ice cover for the present decade (2001-10) and towards the end of this century (2081-90) are indicated in Figure 6. The results of models ECHAM4 and HadCM3 support each other, both predicting moderate reduction in winter ice extent and drastic reduction in the summer. The spatial distributions of the ECHAM4-modelled summer ice cover late in the 21st century (Figure $6 \mathrm{~d}$ ) indicate essentially ice-free Arctic marginal seas, except north of Greenland and the Canadian Arctic Archipelago.

\section{Broader impacts of climate research}

The Nordic countries stretch from the benign climatic zones of southern Scandinavia to high latitudes well above the Arctic circle with true polar winters. The living conditions are intensively influenced by extreme environmental processes and their dynamics in the Arctic. Therefore, its indigenous as well as non-indigenous societies have developed special skills and technologies to live in the area and to exploit its living and other resources, and hence they also have a special interest in studying, exploring and understanding the high latitudes of our Earth including the temporal variability of their environments. Early polar explorers such as Nordenskjöld, Nansen and Amundsen organized audacious expeditions to the Arctic Ocean and 
to Antarctica. This situation changed dramatically close to thirty years ago, when the exploration of the Arctic Ocean gained more urgency and when Swedish scientists started using their large ice breakers for polar research. The highly successful YMER-80 expedition, marking the occasion of the 100th anniversary of Nordenskjöld's crossing of the Northern Sea Route (NSR), led to the iceinfested deep-sea regions to the north of Svalbard. Nowadays, the Scandinavian polar research organisations provide for rich possibilities to carry out sophisticated climate research and ambitious expeditions to marine and terrestrial regions in the high latitudes of both hemispheres.

The scientific and technical achievements resulting from climate research in Norden have strengthened the capacity to detect, understand and predict climate and environmental change, with focus on the high northern latitudes. The scientific and technological achievements of this research are also conveyable to European social objectives and policy. There is a strong need to improve our knowledge base and observation-prediction system for the following important societal issues:

1. Socio-economic and human impact of climate change. There is a need to assess the impact of climate change on a range of issues, such as environmental risk, industrial development, transportation and living conditions.

2. Ecosystems and fisheries: Improved understanding and preservation of the Arctic ecosystem is of high priority in Europe. Climate change can impact fisheries in the Nordic and Barents Seas, which are among the most important in the world.

3. Exploitation of hydrocarbon resources: Europe has significant interest in the exploitation of oil and gas, mineral and other resources in high latitudes, offering opportunities for the European energy and transport industry.

4. Sea transportation: The European shipping industry is preparing for increased use of the Northern Sea Route (NSR), which is a much shorter sailing route between Europe, the Far East and the west coast of North America.

5. Pollution. Europe is responsible for much of the pollution going into the Arctic regions. Improved understanding of the transport of pollutants, including radionuclides, is needed as well as the potential spreading of radionuclides from the Russian Arctic regions.

\section{References}

Bauch, H.A. and Kandiano, E.S., 2007, Evidence for early warming and cooling in North Atlantic surface waters during the last interglacial:, Paleoceanography, v. 22: PA 1201.

Björlykke, K., Elvsborg, A. and Höy, T., 1976, Late Precambrian sedimentation in the central Sparagmite Basin of south Norway: Norsk Geologisk Tidsskrift, v. 56, pp. 233-290.

Bobylev, L.P., Kondratyev, K.Y., Johannessen, O.M., 2003, Arctic Environment Variability in the Context of Global Change: Springer-Praxis Publishing, $470 \mathrm{p}$.

Funder, S., Hjort, C. and Landvik, J.Y., 1994, The last glacial cycles in East Greenland, an overview: Boreas, v. 23, pp. 283-293.

Heer, O., 1876, Flora fossilis arctica. IV(1). Beiträge zur fossilen Flora Spitzbergens: Kongelig Svenska Vetenskap. Akad. Handl, v. 14(5), 141 p.

Holtedal, H., 1955, On the Norwegian Continental terrace, primarily outside Möre-Romsdal: its geomorphology and sediments: Aarbok Bergen University (Naturvitenskapelig Rekke), v. 14, 209 p.

Johannessen, O.M., Campbell, W.J., Shuchman, R.A., Sandven, S., Gloersen, P., Johannessen, J.A., Josberger, E.G. and Haugan, P.M., 1992, Microwave study programs of air-ice-ocean interactive processes in the seasonal ice zone of the Greenland and Barents seas, in Carsey, F. (ed), Microwave Remote Sensing of Sea Ice: American Geophysical Union, Geophysical Monograph, 68, pp. 261-289.

Johannessen, O.M., Shalina, E.V., and Miles, M.W., 1999, Satellite evidence for an Arctic sea ice cover in transformation: Science, v. 286, pp. 1937-1939.

Johannessen, O.M., Bengtsson, L., Miles, M.W., Kuzmina, S.I., Semenov, V. A., Alekseev, G.V., Nagvurny, A.P., Zakharov, V.F., Bobylev, L. P., Petterson, L.H., Hasselmann, K. and Cattle, H.P., 2004, Arctic climate change-observed and modelled temperature and sea ice: Tellus, Series A: Dynamic Meteorology and Oceanography, v. 56A (4), pp. 328-341.

Johannessen, O.M., Khvorostovsky, K., Miles, M.W. and Bobylev, L.P., 2005 , Recent ice-sheet growth in the interior of Greenland: Science, v. 310, pp. 1013-1016.

Mangerud, J., 1982, The Chronostratigraphical Subdivision of the Holocene in Norden; a Review: Striae, v. 16, pp. 65-70.

Myhre, A.M., Thiede, J., Firth, J.V., et al., 1995, North Atlantic Arctic Gateways I: Proceedings Ocean Drilling Program, Initial Reports, v. 151, 926 p. College Station TX

Nansen, F., 1906, Northern Waters: Captain Roald Amundsens oceanographic observations in the Arctic Seas in 1901: Videnskabs-Selskab Skrifter I, Matematikk-Naturvitenskap, v. 3, 145 p.

Nansen, F., 1925, Klimat-vekslinger i Nordens historie: Avhandlinger Norske Videnskabs - Akademi I, Matematikk-Naturvitenskap, v. 3, 63 p.

North Greenland Ice Core Project Members, 2004, High resolution record of northern hemisphere climate extending into the last interglacial period: Nature, v. 431, pp. 147-151.

Olausson, E., 1996, The Swedish Deep-Sea Expedition with the "Albatross" 1947-1948: A summary of the sediment core studies. E. Olausson (Publisher), 98 p., Graabo/Sweden.

St. John, K., in press, Cenozoic ice-rafting history of the central Arctic Ocean: Terrigenous sands on the Lomonosov Ridge: Paleoceanography, v. 23, PA $1 \mathrm{~S} 05$.

Thiede, J. and QUEEN Steering Committee, 2004, What was QUEEN? Its history and international framework: Quaternary Science Reviews: v. 23, pp. 1225-1227.

Wohlfarth, B., Björck, S., Funder, S., Houmark-Nielsen, M., Ingólfsson, Ó., Lunkka, J.-P., Mangerud, J., Saarnisto, M., and Vorren, T., 2008, Quaternary of Norden: Episodes, v.31, no.1. pp.73-81.

Jörn Thiede has been a marine geoscientist and paleontologist for most of his adult life, with emphasis on studying the polar seas. He has held academic positions at US-American, several Scandi-navian and German universities. As its founding director, he helped establish the GEOMAR of Kiel University and later he moved for a decade as director to the AlfredWegener-Institute for Polar and Marine Research. He is now dreaming to establish a novel international research icebreaker capable to operate during all seasons and to carry out deep-sea drilling in the permanently ice-infested waters of the central Arctic Ocean.

Ola M. Johannessen is the Founding Director of the Nansen Environmental and Remote Sensing Center/ Geophysical Institute, University of Bergen since 1987. OMJ is presently involved in the following scientific fields: global warming detection and prediction of the Arctic climate system, including sea ice, Greenland ice sheet and deep water formation and its impact on the thermohaline circulation. OMJ is elected full member of the International Academy of Astronautics, the European Academy of Science and Arts, Finnish Academy of Science and Letters, the Nor-wegian Academy of Technical Sciences and the Norwegian Academy of Science and Letters.
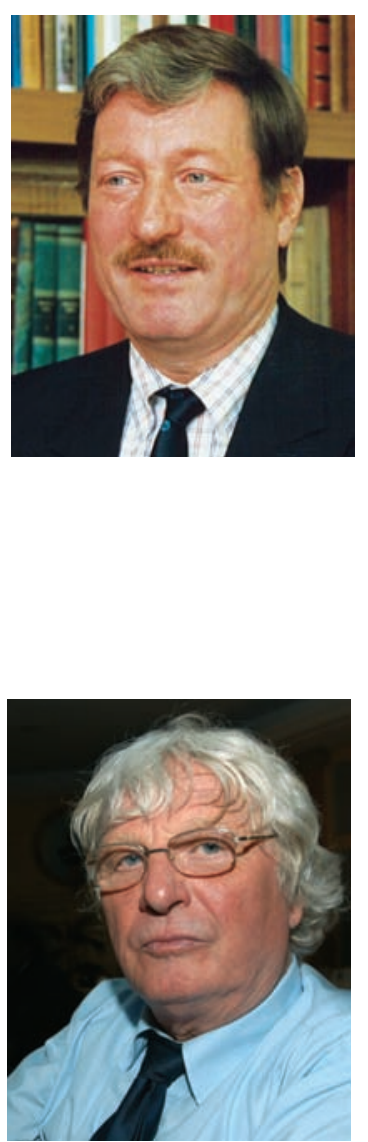